\title{
HUBUNGAN ANTARA USIA, JENIS KELAMIN, DAN TINGKAT PENDIDIKAN DENGAN KEJADIAN DIABETES MELLITUS DI KLINIK MARDI WALUYO LAMPUNG TENGAH
}

\author{
Resti Arania1, Tusy Triwahyuni², Firhat Esfandiari ${ }^{3}$, Fidel Rama Nugraha ${ }^{4}$ \\ ${ }^{1}$ Departemen Patologi Anatomi Rumah Sakit Umum Dr.H Abdul Moeloek \\ ${ }^{2}$ Departemen Parasitologi Fakultas Kedokteran Universitas Malahayati \\ ${ }^{3}$ Departemen Penyakit Dalam Rumah Sakit Mardi Waluyo Metro \\ ${ }^{4}$ Program Studi Kedokteran Fakultas Kedokteran Universitas Malahayati
}

[email korespondensi: fidellrama9@gmail.com]

\begin{abstract}
Relationship Between Age, Gender, And Education Level With Diabetes Mellitus At The Clinic Mardi Waluyo Lampung Tengah. Diabetes mellitus (DM) is a chronic disease that occurs when the body cannot produce enough insulin (a hormone that controls blood sugar or glucose) due to pancreatic disorders, or the body cannot efficiently utilize the insulin it produces. Diabetes mellitus is a serious population health problem, and one of four non-communicable diseases that need to be followed up. It should be noted that in the last ten years the number and prevalence of diabetes mellitus has continued to increase. Diabetes mellitus is the eighth cause of death of both sexes and the fifth cause of death in women. The purpose of this study is the relationship between age, gender, and education level with the incidence of diabetes mellitus at the Mardi Waluyo clinic in Central Lampung in 2020. The method of this study is an analytic observational study, the data obtained are secondary data from patients with suspected diabetes mellitus. Sampling using the Lemeshow formula with an unknown population to get 126 samples. The analysis that will be used is bivariate analysis with the Spearman Correlation test. The results obtained were that there were 93 respondents $(73.8 \%)$ who had diabetes mellitus, $47(87.0 \%)$ middle adults, 72 women $(79.1 \%)$ and 51 people $(85.0 \%)$ with basic education. In this study, there is a relationship between age, gender, and level of education with the incidence of diabetes mellitus in the Central Mardi Waluyo Clinic in 2020.
\end{abstract}

Keywords: Diabetes Mellitus, Age, Gender, Education Level

Abstrak: Hubungan Antara Usia, Jenis Kelamin, Dan Tingkat Pendidikan Dengan Kejadian Diabetes Mellitus Di Klinik Mardi Waluyo Lampung Tengah. Diabetes mellitus (DM) merupakan penyakit kronis yang terjadi ketika tubuh tidak dapat menghasilkan cukup insulin (hormon yang mengontrol gula darah atau glukosa) karena gangguan pankreas, atau tubuh tidak dapat secara efisien memanfaatkan insulin yang diproduksi. Diabetes mellitus adalah masalah kesehatan penduduk yang serius, dan salah satu dari empat penyakit tidak menular yang perlu ditindak lanjuti. Perlu diketahui bahwa dalam sepuluh tahun terakhir jumlah dan prevalensi diabetes mellitus terus meningkat. Diabetes mellitus adalah penyebab kematian kedelapan dari kedua jenis kelamin dan penyebab kematian kelima pada wanita. Tujuan Penelitian ini adalah Hubungan antara Usia, Jenis Kelamin, dan Tingkat Pendidikan dengan Kejadian Diabetes Melitus di Klinik Mardi Waluyo Lampung Tengah Tahun 2020. Metode penelitian ini adalah Penelitian ini bersifat observasional analitik, data yang diperoleh berupa data sekunder pasien suspect diabetes mellitus. Pengambilan sampel dengan menggunakan rumus Lemeshow dengan populasi tidak diketahui sehingga mendapatkan 126 sampel. Analisis yang akan digunakan adalah analisis bivariat dengan uji Korelasi Spearman. Hasil yang didapat adalah Diketahui responden yang mengalami diabetes mellitus sebanyak 93 orang $(73.8 \%)$, berusia dewasa tengah sebanyak 47 
orang $(87.0 \%)$, sebanyak 72 orang $(79.1 \%)$ berjenis kelamin perempuan dan sebanyak 51 orang $(85.0 \%)$ berpendidikan dasar Kesimpulan pada penelitian ini adalah Terdapat hubungan antara usia, jenis kelamin, dan tingkat Pendidikan dengan kejadian diabetes mellitus di klinik mardi waluyo lampung tengah tahun 2020.

Kata Kunci: Diabetes Melitus, Usia, Jenis Kelamin, Tingkat Pendidikan

\section{PENDAHULUAN}

Diabetes

mellitus

(DM)

merupakan penyakit kronis yang terjadi ketika tubuh tidak dapat menghasilkan cukup insulin (hormon yang mengontrol gula darah atau glukosa) karena gangguan pankreas, atau tubuh tidak dapat secara efisien memanfaatkan insulin yang diproduksi. Diabetes mellitus adalah masalah kesehatan penduduk yang serius, dan salah satu dari empat penyakit tidak menular yang perlu ditindak lanjuti. Perlu diketahui bahwa dalam sepuluh tahun terakhir jumlah dan prevalensi diabetes mellitus terus meningkat. Diabetes mellitus adalah penyebab kematian kedelapan dari kedua jenis kelamin dan penyebab kematian kelima pada wanita. Pada tahun 2015, kejadian diabetes terbesar di dunia adalah China, India, Amerika Serikat, Brazil, Rusia dan Meksiko, dengan perkiraan 10 juta penderita diabetes (WHO, 2016).

Diperkirakan orang yang paling berisiko terkena diabetes mellitus berasal dari Asia Tenggara dan Pasifik Barat. Antara tahun 1980 dan 2014, jumlah pasien diabetes mellitus di seluruh dunia meningkat secara substansial, jumlah pasien diabetes mellitus meningkat dari 108 juta menjadi 422 juta, meningkat kurang lebih empat kali lipat (WHO, 2010).

Berdasarkan KEMENKES (2013), prevalensi pasien diabetes mellitus di Indonesia terus meningkat, dari 5,7\% pada 2007 menjadi $6,9 \%$ pada 2013. Di Indonesia, dua pertiga penderita diabetes mellitus tidak menyadari penyakit diabetes mellitusnya dan potensinya untuk mendapatkan perawatan kesehatan jika terjadi komplikasi. Prevalensi kegemukan atau kegemukan sebesar 13,5\%, dan angka obesitas sebesar $15,4 \%$ yang merupakan salah satu faktor risiko diabetes mellitus terbesar dan terus meningkat.

Menurut KEMENKES (2013)

kasus diabetes mellitus seringkali lebih tinggi pada orang dengan pendidikan tinggi. Pada tahun 2009 kasus diabetes mellitus di puskesmas rawat jalan Provinsi Lampung rata-rata mencapai 365 per bulan, dan bertambah menjadi 1.103 pada tahun 2010. Sementara menurut Dinas Kesehatan Lampung Tengah, angka kasus diabetes mellitus di Kabupaten Lampung Tengah meningkat 9\% menjadi 581 kasus.

Diabetes mellitus merupakan penyakit kronis progresif yang dapat menimbulkan berbagai komplikasi pada organ lain, terutama saraf, ginjal, mata, pembuluh darah, dan jantung. Gejala berupa poliuria, polidipsi, penurunan berat badan, terkadang polifagia dan penglihatan kabur. Data WHO mengungkapkan bahwa diabetes mellitus mengakibatkan sekitar 4\% kematian dari semua kematian di dunia (Sirait, 2015). Tidak ada obat untuk diabetes, tetapi kadar gula darah dapat dikontrol melalui diet, olahraga, dan pengobatan. Untuk mencegah komplikasi kronis dibutuhkan pengendalian diabetes mellitus yang baik (PERKENI, 2011). Prevalensi Disfungsi Ereksi (DE) pada pasien diabetes mellitus di usia remaja sangat tinggi akibat neuropati, saraf otonom, penyakit pembuluh darah dan masalah psikologis, namun pasien jarang berkomunikasi (PERKENI, 2015).

Orang yang memiliki tingkat pendidikan tinggi biasanya memiliki pengetahuan tentang kesehatan sehingga orang akan memiliki kesadaran dalam menjaga kesehatan (Irawan, 2010).

Menurut Darusman (2009), jenis kelamin menjadi salah satu faktor yang mempengaruhi perilaku kesehatan, 
termasuk pengaturan pola makan. Wanita lebih kerap menggunakan perawatan kesehatan daripada pria, dan wanita lebih sering berpartisipasi dalam pemeriksaan medis. Secara umum, wanita lebih cenderung memperhatikan, menjaga kesehatan dan menjalani pengobatan dibandingkan pria. Berdasarkan penelitian Lathifah (2017) ditemukan bahwa $52 \%$ responden penderita diabetes mellitus tipe 2 bercirikan laki-laki, dan sebanyak $48 \%$ perempuan.

Menurut penelitian Susilawati dan Muljati (2016), kelompok usia terbagi menjadi dua jenis, yaitu kelompok risiko tinggi pada usia 40 tahun dan kelompok risiko rendah di bawah 40 tahun. Rentang usia 15 hingga 98 tahun, dengan rata-rata usia 39,87 tahun. Batasan usia 40 tahun dijadikan sebagai batasan risiko penyakit. Kebanyakan penderita diabetes mellitus berusia antara 40 dan 60 tahun.

Berdasarkan data di atas menyebabkan peneliti tertarik untuk meneliti faktor risiko usia,jenis kelamin dan tingkat pendidikan pada pasiendiabetes mellitus pada masyarakat Lampung Tengah. Penelitian ini diharapkan dapat meningkatkan kewaspadaan dini terhadap diabetes mellitus, sehingga seseorang dengan faktor risiko diabetes mellitus dapat dideteksi sejak dini sebelum mengalami komplikasi.

\section{METODE}

Penelitian ini bersifat observasional analitik, data yang diperoleh berupa data sekunder yang diperoleh dari rekam medis dengan mengambil data Usia, Jenis Kelamin dan Tingkat Pendidikan pasien suspect diabetes mellitus. Penelitian dilakukan dari bulan Oktober 2020 hingga Februari 2021. Pengambilan sampel dengan menggunakan rumus Lemeshow dengan populasi tidak diketahui sehingga mendapatkan 126 sampel. Analisis yang akan digunakan adalah analisis bivariat dengan uji Korelasi Spearman.

\section{HASIL}

Tabel 1. Distribusi Responden Berdasarkan Usia, Jenis Kelamin dan Tingkat Pendidikan di Klinik Mardi Waluyo Lampung Tengah Tahun 2020

\begin{tabular}{llll}
\hline No. & Karakteristik & Jumlah & Persentase \\
\hline 1 & Usia & 12 & $9.5 \%$ \\
& Dewasa Awal & 54 & $42.9 \%$ \\
& Dewasa Tengah & 60 & $47.6 \%$ \\
\hline 2 & Dewasa Lanjut & 35 & $27.8 \%$ \\
& Jenis Kelamin & 91 & $72.2 \%$ \\
& Laki-laki & & $47.6 \%$ \\
& Perempuan & 60 & $27.0 \%$ \\
& Tingkat Pendidikan & Dasar (SD, SMP) & $25.4 \%$ \\
& Menengah & & \\
& (SMA,Kejuruan) & 34 & \\
& Tinggi (Perguruan tinggi) & 32 & \\
\hline
\end{tabular}

Dari hasil penelitian didapatkan responden kelompok dewasa awal sebanyak 12 orang $(9.5 \%)$, dewasa tengah sebanyak 54 orang $(42.9 \%)$ dan dewasa lanjut sebanyak 60 orang $(47.6 \%)$. Dan responden yang berjenis kelamin lak-laki sebanyak 35 orang
(27.8\%) dan perempuan sebanyak 91 orang $(72.2 \%)$. Dan responden yang berpendidikan dasar sebanyak 60 orang $(47.6 \%)$, menengah sebanyak 34 orang $(27.0 \%)$ dan perguruan tinggi sebanyak 32 orang $(25.4 \%)$. 
Tabel 2. Distribusi Frekuensi Responden Berdasarkan Penyakit Diabetes Mellitus di Klinik Mardi Waluyo Lampung Tengah Tahun 2020

\begin{tabular}{llll}
\hline No. & Karakteristik & Jumlah & Persentase \\
\hline 1 & Diabetes Mellitus & & $26.2 \%$ \\
& Tidak diabetes mellitus & 33 & $73.8 \%$ \\
\hline
\end{tabular}

Dari hasil penelitian didapatkan distribusi frekuensi responden yang tidak mengalami diabetes mellitus

sebanyak 33 orang (26.2\%), dan yang mengalami diabetes mellitus sebanyak 93 orang $(73.8 \%)$ (Tabel 2$)$.

Tabel 3. Hasil Uji Spearman Hubungan Usia, Jenis Kelamin dan Tingkat Pendidikan dengan Kejadian Diabetes Mmellitus di Klinik Mardi Waluyo Lampung Tengah Tahun 2020.

\begin{tabular}{|c|c|c|c|c|c|}
\hline \multirow[b]{2}{*}{ No } & \multirow{2}{*}{ Variabel } & \multicolumn{2}{|c|}{ Diabetes Mellitus } & \multirow[t]{2}{*}{ Keterangan } & \multirow[b]{3}{*}{ yang } \\
\hline & & $\mathbf{P}$ & $\mathbf{R}$ & & \\
\hline 1 & Usia & 0.016 & 0.215 & $\begin{array}{l}\text { Ada Hubungan } \\
\text { Signifikan }\end{array}$ & \\
\hline 2 & Jenis Kelamin & 0.029 & 0.195 & $\begin{array}{l}\text { Ada Hubungan } \\
\text { Lemah }\end{array}$ & yang \\
\hline 3 & $\begin{array}{l}\text { Tingkat } \\
\text { Pendidikan }\end{array}$ & 0.000 & -0.340 & $\begin{array}{l}\text { Ada Hubungan } \\
\text { Signifikan }\end{array}$ & yang \\
\hline
\end{tabular}

Hasil analisis hubungan antara usia dengan kejadian diabetes melitus dengan diperoleh nilai $p$-value $=0.016$. Hal ini menunjukkan bahwa ada korelasi yang signifikan antara usia dengan kejadian diabetes melitus dan juga menampilkan nilai korelasi sebesar 0.215 . Nilai ini menunjukkan korelasi antara usia dengan kejadian diabetes melitus dan bernilai positif yang artinya bertambahnya usia seseorang dapat meningkatkan kejadian diabetes melitus.

Hasil analisis hubungan antara jenis kelamin dengan kejadian diabetes melitus dengan diperoleh nilai $p$-value $=$ 0.029 . Hal ini menunjukkan bahwa ada korelasi yang lemah antara jenis kelamin dengan kejadian diabetes melitus dan juga menampilkan nilai korelasi sebesar 0.195. Nilai ini menunjukkan korelasi antara jenis kelamin dengan kejadian diabetes melitus dan bernilai positif yang artinya jenis kelamin seseorang dapat meningkatkan kejadian diabetes melitus.

Hasil analisis hubungan antara tingkat pendidikan dengan kejadian diabetes melitus dengan diperoleh nilai $p$-value $=0.000$. Hal ini menunjukkan bahwa ada korelasi yang signifikan antara tingkat pendidikan dengan kejadian diabetes melitus dan juga menampilkan nilai korelasi sebesar 0.340. Nilai ini menunjukkan korelasi antara tingkat pendidikan dengan kejadian diabetes melitus dan bernilai negatif yang artinya semakin tinggi tingkat pendidikan seseorang dapat menekan kejadian diabetes melitus.

\section{PEMBAHASAN}

1. Usia

Batasan usia menggunakan teori penuaan (aging) yang terjadi secara perlahan-lahan dibagi menjadi beberapa tahapan. Tahap transisi terjadi pada usia 35-45 tahun dan merupakan tahap mulai terjadinya gejala penuaan yang sudah menunjukkan terjadinya tandatanda penurunan fungsi fisiologis dalam tubuh yang dapat bermanifestasi pada berbagai penyakit. Gejala dan tanda penuaan yang terjadi pada tahap transisi menjadi lebih nyata, tahap ini disebut tahap klinik yang terjadi pada usia 45 tahun ke atas yang meliputi penurunan semua fungsi sistem tubuh, antara lain sistem imun, metabolisme, 
endokrin, seksual dan reproduksi, kardiovaskuler, gastrointestinal, otot dan saraf. Penyakit degeneratif mulai terdiagnosis, aktivitas dan kualitas hidup berkurang akibat ketidakmampuan baik fisik maupun psikis yang sangat terganggu (Fedarko, 2012). Hasil penelitian ini didukung oleh penelitian Sharma (2015), dimana subjek terbesar mengalami diabetes mellitus pada kelompok usia 51-60 tahun.

\section{Jenis Kelamin}

Hormon estrogen dan progesterone memiliki kemampuan untuk meningkatkan respon insulin di dalam darah. Pada saat masa menopause terjadi, maka respon akan insulin menurun akibat hormone estrogen dan progesterone yang rendah. Faktor lain yang berpengaruh adalah berat badan perempuan yang sering tidak ideal sehingga hal ini dapat menurunkan sensitivitas respon insulin. Hal inilah yang membuat perempuan sering terkena diabetes daripada lakilaki (Meidikayanti, 2017). Hal ini sesuai juga dengan pernyataan Taylor (2002), yang menyatakan bahwa penyebab utama banyaknya perempuan terkena diabetes mellitus tipe 2 karena terjadinya penurunan hormon estrogen terutama pada masa menopause.

\section{Tingkat Pendidikan}

Orang yang tingkat

pendidikannya tinggi biasanya akan memiliki banyak pengetahuan tentang kesehatan, tingkat pendidikan juga mempengaruhi aktivitas fisik seseorang karena terkait dengan pekerjaan yang dilakukan. Orang yang tingkat pendidikan tinggi biasanya lebih banyak bekerja di kantoran dengan aktivitas fisik sedikit sedangkan yang tingkat pendidikan rendah lebih banyak menjadi buruh maupun petani dengan aktivitas fisik yang cukup (KEMENKES, 2013). Selain itu dalam KEMENKES (2013) juga didapatkan proporsi penderita diabetes mellitus menurut pendidikan lebih tinggi pada kelompok dengan pendidikan rendah atau dasar. Hasil penelitian di atas sejalan dengan penelitian Miranti (2017) di mana sebagian besar responden berpendidikan dasar $(73.0 \%)$.

\section{Kejadian Diabetes mellitus}

Diabetes mellitus merupakan penyakit kronik yang dapat terjadi disaat tubuh tidak dapat memproduksi insulin yang cukup yaitu hormon tubuh yang dapat mengatur gula dalam darah yang disebabkan karena adanya gangguan pada pankreas, atau kondisi dimana tubuh tidak dapat menggunakan insulin yang diproduksi oleh tubuh. Diabetes mellitus adalah salah satu dari 4 penyakit tidak menular yang perlu ditindak lanjuti. Diketahui bahwa dalam beberapa dekade terakhir, jumlah kasus diabetes dan prevalensi diabetes terus meningkat (WHO, 2016). Penyakit ini tidak hanya menyerang orang dewasa, tetapi juga dapat menyerang anakanak. Diabetes mellitus ditandai dengan peningkatan kadar gula dalam darah yang disebabkan oleh terganggunya produksi insulin, gangguan kerja insulin, atau keduanya (Skyler, 2017).

Faktor risiko DM tipe 2 dikategorikan menjadi beberapa faktor yaitu sosiodemografi, riwayat kesehatan, pola hidup, dan kondisi klinis serta mental. Adapun faktor sosiodemografi terdiri dari umur, jenis kelamin, pendidikan dan pekerjaan. Sedangkan faktor riwayat kesehatan mencakup riwayat penyakit keturunan diabetes mellitus dalam keluarga dan berat lahir. Faktor-faktor pola hidup itu terdiri dari aktivitas fisik, konsumsi sayur dan buah, paparan asap rokok serta konsumsi alkohol. Sementara itu, faktor kondisi klinis dan mental pasien itu terdiri dari lingkar pinggang, tekanan darah, indeks massa tubuh dan stres (Irawan, 2010).

\section{Hubungan Antara Usia dengan Kejadian Diabetes Mellitus}

Hasil penelitian di atas sejalan dengan penelitian John (2014) dimana hasil penelitian menunjukkan bahwa terdapat hubungan yang signifikan antara umur dengan kejadian diabetes mellitus tipe $2(p$-value $=0.000)$. Hasil yang sama juga diperoleh pada penelitian yang dilakukan oleh Zahtamal (2007) terhadap 152 responden yang 
menunjukkan bahwa hubungan umur dengan kejadian diabetes melitus.

Prevalensi diabetes akan

semakin meningkat seiring dengan semakin meningkatnya umur, hingga kelompok usia lanjut (Alkhalaf, 2007). Kekuatan fisik dan mekanisme pertahanan tubuh cenderung menurun dengan bertambahnya usia dan tubuh tidak lagi mampu menghadapi pilihan gaya hidup yang tidak sehat, yang pada akhirnya menghasilkan manifestasi penyakit seperti diabetes. Diperkirakan bahwa pada tahun 2030 di seluruh dunia, jumlah terbesar individu dengan diabetes mellitus adalah usia 45-64 tahun (Sharma, 2015).

Menurut Smeltzer dan Bare (2008), mayoritas penderita diabetes mellitus tipe 2 paling banyak dialami oleh orang-orang berada di usia 40 tahun ke atas. Hal ini disebabkan karena pada umur 40 tahun ke atas retensi insulin pada diabetes mellitus tipe 2 akan semakin meningkat di samping terdapat riwayat keturunan dan obesitas. WHO mengasumsikan bahwa setelah umur 30 tahun, maka kadar glukosa darah akan naik 1-2 $\mathrm{mg} / \mathrm{dL} /$ tahun sedangkan pada saat puasa akan naik $5.6-13 \mathrm{mg} / \mathrm{dL}$, pada saat 2 jam setelah makan (Meidikayanti, 2017). Meskipun pada umumnya diabetes melitus terjadi pada usia pertengahan atau pada orang yang lanjut usia. Namun, seiring dengan epidemi global, terdapat tren diabetes melitus tipe 2 muncul pada usia yang lebih awal dikarenakan pola hidup yang tidak sehat.

\section{Hubungan Antara Jenis Kelamin dengan Kejadian Diabetes Mellitus}

Hasil penelitian di atas sejalan dengan penelitian Nina (2017) dimana dari hasil penelitian diperoleh ada hubungan antara jenis kelamin dengan resiko diabetes mellitus dengan diperoleh nilai $p$-value $=0.000$. Hasil penelitian di atas sejalan juga dengan penelitian yang dilakukan oleh (Prasetyani, 2016), hasil penelitian menunjukkan terdapat hubungan yang signifikan antara jenis kelamin dengan kejadian diabetes mellitus tipe 2 .

Tingginya kejadian diabetes mellitus pada perempuan dapat disebabkan oleh adanya perbedaan komposisi tubuh dan perbedaan kadar hormon seksual antara perempuan dan laki-laki dewasa. Perempuan memiliki jaringan lemak yang lebih banyak dibandingkan laki-laki. Hal ini dapat diketahui dari perbedaan kadar lemak normal antara laki-laki dan perempuan dewasa, dimana pada laki-laki berkisar antara $15-20 \%$ sedangkan pada perempuan berkisar antara $20-25 \%$ dari berat badan. Penurunan konsentrasi hormon estrogen pada perempuan menopause menyebabkan peningkatan cadangan lemak tubuh terutama di daerah abdomen yang akan meningkatkan pengeluaran asam lemak bebas. Kedua kondisi ini menyebabkan resistensi insulin (Prasetyani, 2016).

$$
\text { Taylor (2002) menyatakan }
$$

bahwa penyebab utama banyaknya perempuan terkena diabetes mellitus tipe 2 karena terjadinya penurunan hormon estrogen terutama saat masa menopause. Hormon estrogen dan progesterone memiliki kemampuan untuk meningkatkan respon insulin di dalam darah. Pada saat masa menopause terjadi, maka respons insulin menurun akibat hormone estrogen dan progesterone yang rendah. Namun baik perempuan maupun laki-laki hendaknya lebih berhati-hati terhadap penyakit diabetes mellitus dan berupaya untuk menjaga kadar gula darah dengan mengubah kebiasaan makan dan aktivitas fisik, serta menghindari hal-hal yang dapat menimbulkan peningkatan indek massa tubuh dan meningkatkan kadar gula darah.

\section{Hubungan Antara Tingkat Pendidikan dengan Kejadian Diabetes Mellitus}

Hasil penelitian di atas sejalan dengan penelitian Nina (2017) dimana terdapat hubungan yang bermakna anta tingkat pendidikan dengan kejadian diabetes mellitus dengan diperoleh nilai $p$-value $=(0.001)$. 
Menurut Notoatmodjo (2012), tingkat pendidikan seseorang yang rendahh akan susah mencerna pesan atau informasi yang disampaikan. Masyarakat berpendidikan tinggi akan lebih mudah menerima pesan atau informasi yang disampaikan orang lain karena berdasarkan pengalaman dan budaya yang ada pada masyarakat setempat.

Menurut Notoatmodjo (2012) mengatakan bahwa tingkatan pendidikan merupakan salah satu yang tidak bisa lepas pada proses belajar. Dengan makna lain belajar merupakan usaha seseorang untuk mendapatkan informasi lebih yang bisa digunakan dalam kelangsungan hidup. Hasil penelitian di atas diketahui sebagian besar responden berpendidikan dasar. Ini mempunyai peranan penting dalam terjadinya kasus diabetes mellitus dan dislipidemia. Dari segi tingkat pendidikan mereka kesulitan menyerap informasi yang diterima dari sosialisasi yang diberikan oleh pihak kesehatan.

\section{KESIMPULAN}

Usia, jenis kelamin dan tingkat pendidikan merupakan faktor yang berhubungan terhadap kejadian Diabetes Mellitus. Hendaknya masyarakat lebih berhati-hati terhadap penyakit diabetes mellitus dan berupaya untuk menjaga kadar gula darah dengan mencegah serta mencaritahu informasi terkait dengan faktor resiko yang dapat menyebabkan terjadinya diabetes mellitus bisa melalui media sosial maupun fasilitas kesehatan yang membagikan brosur atau dari banner tentang kesehatan lainnya.

\section{DAFTAR PUSTAKA}

Alkhalaf, M., Al-Bustan, S., Hamoda, H., \& Abdella, N. (2007). Polymorphism of p53 Gene Codon 72 In Kuwaiti with Coronary Artery Disease and Diabetes. International journal of cardiology 115(1): 1-6.

Darusman. (2009). Perbedaan Perilaku Pasien Diabetes Melitus Pria dan Wanita dalam Mematuhi Pelaksanaan Diet. Berita
Kedokteran Masyarakat Universitas Gadjah Mada 25(1): 31-33.

Fedarko, N.S. (2012). The Biology of Aging and Frailty. Journal NCBI 27(1): 27-37.

Irawan, D. (2010). Prevalensi dan Faktor Resiko Kejadian Diabetes Mellitus Tipe 2 di Daerah Urban Indonesia. [Skripsi]. Jakarta: Universitas Indonesia.

John, S.K, Budi, T.R, Gloria W. (2014). Analisis Hubungan Antara Umur dan Riwayat Keluarga Menderita DM Dengan Kejadian Penyakit DM Tipe 2 Pada Pasien Rawat Jalan Di Poliklinik Penyakit Dalam Blu Rsup Prof. Dr. R.D Kandou Manado. [Skripsi]. Manado: Universitas Sam Ratulangi.

Kementerian Kesehatan Indonesia. (2013). Hasil Riskesdas 2013. Jakarta: Kementrian Kesehatan Republik Indonesia.

Lathifah, N.L. (2017). Hubungan Antara Karakteristikla Penderita, Durasi Penyakit, Keteraturan Periksa, dan Kadar Gula Darah dengan Keluhan Subjektif Pada Penderita Diabetes Melitus Tipe 2. [Skripsi]. Surabaya: Universitas Airlangga.

Meidikayanti, W. (2017). Hubungan Dukungan Keluarga Dan Aktivitas Fisik Dengan Kualitas Hidup Diabetes Mellitus Tipe 2. [Skripsi]. Surabaya: Universitas Airlangga.

Miranti. P, Ari. U, Sri.Y. (2017) Gambaran Karakteristik Pasien Komplikasi Diabetes Di Rumah Sakit Kristen Ngesti Waluyo Parakan. [Skripsi]. Semarang: Universitas Diponegoro.

Notoatmodjo, Soekidjo. (2012). Pendidikan dan perilaku kesehatan. Jakarta: Rineka Cipta.

Nina, W. (2017) Hubungan Karakteristik Responden dengan Risiko Diabetes Melitus dan Dislipidemia Kelurahan Tanah Kalikedinding. [Skripsi]. Surabaya: Universitas Airlangga. 
Perkumpulan Endkrionologi Indonesia. (2011). Konsensus Pengelolaan dan Pencegahan Diabetes Melitus Tipe 2 di Indonesia. Jakarta: PB PERKENI.

Perkumpulan Endokrinologi Indonesia. (2015) Konsensus Pengendalian dan Pencegahan Diabetes Melitus Tipe 2 di Indonesia. Jakarta: PB PERKENI.

Prasetyani, D.S. (2016). Hubungan Dukungan Keluarga dengan Kemampuan Self-Care pada Pasien Diabetes Mellitus Tipe-2. Jurnal Kesehatan Al-Irsyad 9 (2).

Sharma. S., Singh, H., Ahmad. H., Mishra. P., Tiwari. A. (2015). The Role of melatonin in diabetes: theraupetic implications. PUBMED Journal 9(5):391-9.

Sirait, A. M. Sulistiowati, A. (2015) Insiden dan Faktor Risiko Diabetes Mellitus pada Orang Dewasa di Kota Bogor. Buletin Penelitian Sistem Kesehatan 18(2): 43.

Smeltzer dan Bare. (2008). Teksbook of Medical Surgical Nursing Vol 2. Philadelphia: Lippincott William \& Wilkins.

Susilawati. Made, D. Muljati, S. (2016) Perbandingan IMT dan Indikator Obesitas Sentral terhadap Kejadian Diabetes Mellitus Tipe 2. Jurnal Litbang Kemkes 43(1): 17-22.

Skyler, J. S., Bakris, G. L., Bonifacio, E., Darsow, T., Eckel, R. H., Groop, L., \& Ratner, R. E. (2017). Differentiation of diabetes by pathophysiology, natural history, and prognosis. Diabetes 66(2): 241-255.

Taylor, R., Lee, C., Kyne-Grzebalski, D., Marshall, S. M., \& Davison, J. M. (2002). Clinical outcomes of pregnancy in women with type 1 diabetes. Obstetrics \& Gynecology 99(4): 537-541.

World Health Organization (2010) Global report on diabetes. WHO Library Cataloguing-inPublication Data. 58(12): 1-88.

World Health Organization. (2016) Obesity and Overweight.
Available at: www.who.int/newsroom/fact-sheets/detail/obesityand-overweight (accessed: 5 September 2020).

Zahtamal. Chandra, F. Suryanto. dan Restuastuti, T. (2007) FaktorFaktor Risiko Pasien Diabetes Mellitus. Berita Kedokteran Masyarakat 23(3): 7-14. 